\title{
Lenalidomide-associated arterial thrombosis in a patient with JAK2 positive atypical myeloproliferative neoplasm
}

\author{
Tanesh Kumar Ayyalu, ${ }^{1}$ Meltiady Issa ${ }^{2}$
}

${ }^{1}$ Medicine, Amrita Institute of Medical Sciences and Research Centre, Cochin, India

2Department of Medicine, Mayo Clinic Division of Hospital Internal Medicine, Rochester, Minnesota, USA

\section{Correspondence to}

Dr Meltiady Issa MD, MBA issa.meltiady@mayo.edu

Accepted 5 August 2017

\section{DESCRIPTION}

A 71-year-old woman, with a recent diagnosis of JAK2 positive atypical myeloproliferative neoplasm, presented to the emergency room (ER) for bilateral foot pain and purplish discolouration of her toes (figure 1). She started her first cancer treatment 3 weeks ago using lenalidomide with prednisone $20 \mathrm{mg}$ daily. Venous thromboprophylaxis was not prescribed then due to anaemia and history of intracranial haemorrhage. ER work up included simple X-rays of her feet that were normal. Lower extremity ultrasound did not show any deep vein thrombosis, so she was discharged home. The patient did not have atrial fibrillation or hyperviscosity. No history of arterial thrombosis or smoking. Two weeks later, she was re-evaluated by her haematologist, and a hospital admission was arranged given worsening symptoms. Her physical exam now showed the purplish discolouration has progressed over both feet, associated with some toes turning black (figure 2). She had strong lower extremity pulses. Arterial lower extremity ultrasound showed normal ankle-brachial indices with no large vessel

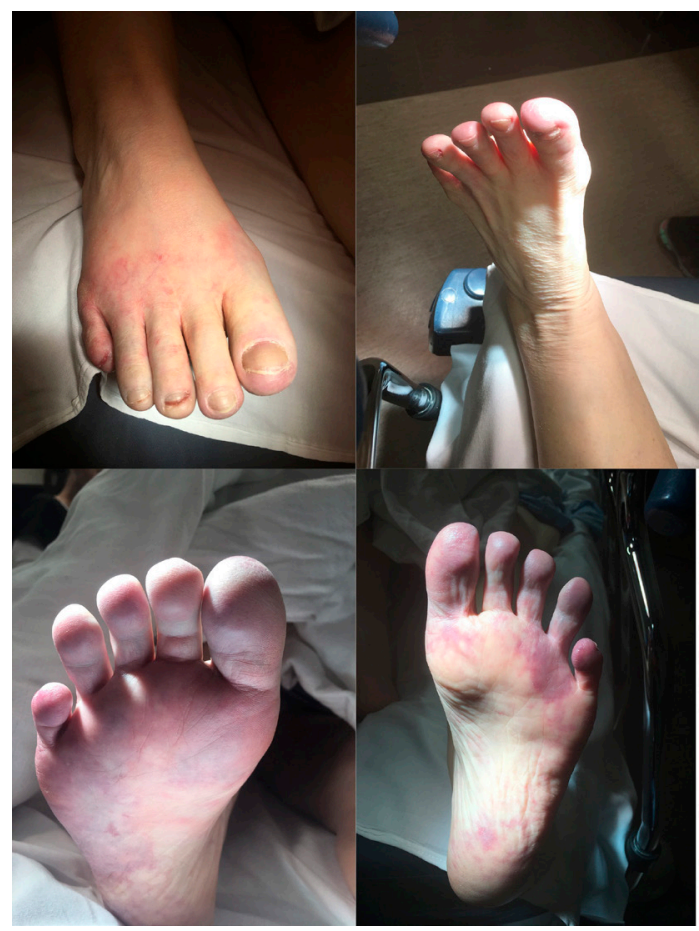

Figure 1 Plantar and dorsal aspect of both feet, showing mild purplish discolouration.

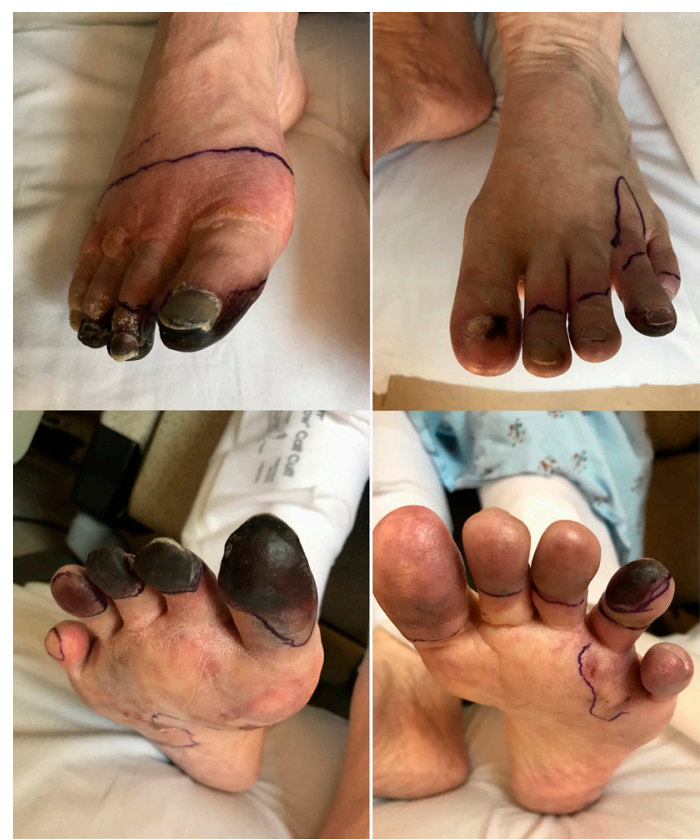

Figure 2 Plantar and dorsal aspect of both feet 2 weeks later, showing significant progression and development of gangrenous changes on multiple toes.

arterial disease. Heparin infusion was started given her gangrenous changes. Lenalidomide was discontinued. A CT angiogram of the aorta and large vessels looking for any embolic source was negative. Echocardiogram was normal. Her presentation was consistent with lenalidomide-induced arterial thrombosis. On discharge, she opted for a palliative approach with hospice. She passed away a month later.

While lenalidomide has been associated with an increased risk of venous thromboembolism, arterial thrombotic events are less common but can

Learning points

- While usually well tolerated, lenalidomide therapy can increase the thromboembolism risk, which, if not recognised early, can lead to significant complications.

- Thromboprophylaxis should be considered to prevent both venous and arterial events with lenalidomide therapy, based on risk factors and immunomodulators. 
be catastrophic. ${ }^{1}$ Prevention and early recognition is key to improve morbidity and mortality. ${ }^{2}$

Contributors We (TKA and MI) certify that we have participated sufficiently in the work to take public responsibility for the content, including participation in the concept, design, analysis and writing of the manuscript. We both have made substantial contributions to the work reported in the manuscript.

Competing interests None declared.

Patient consent Obtained.

Provenance and peer review Not commissioned; externally peer reviewed. (c) BMJ Publishing Group Ltd (unless otherwise stated in the text of the article) 2017. All rights reserved. No commercial use is permitted unless otherwise expressly granted.

\section{REFERENCES}

1 Dimopoulos MA, Anagnostopoulos A, Weber D. Treatment of plasma cell dyscrasias with thalidomide and its derivatives. I Clin Oncol 2003;21:4444-54.

2 Maharaj S, Chang S, Seegobin K, et al. Increased risk of arterial thromboembolic events with combination lenalidomide/dexamethasone therapy for multiple myeloma. Expert Rev Anticancer Ther 2017;17:585-91.

Copyright 2017 BMJ Publishing Group. All rights reserved. For permission to reuse any of this content visit http://group.bmi.com/group/rights-licensing/permissions.

BMJ Case Report Fellows may re-use this article for personal use and teaching without any further permission.

Become a Fellow of BMJ Case Reports today and you can:

- Submit as many cases as you like

- Enjoy fast sympathetic peer review and rapid publication of accepted articles

- Access all the published articles

- Re-use any of the published material for personal use and teaching without further permission

For information on Institutional Fellowships contact consortiasales@bmjgroup.com

Visit casereports.bmj.com for more articles like this and to become a Fellow 